\title{
Effect of Rutin on the Isolated Rat Duodenum and Comparison with the Effects of Adrenaline, Isoprenaline and Papaverine.
}

\author{
Rutin'in İzole Siçan Duodenumu Üzerine Etkisi ve Adrenalin, İzo- \\ prenalin, Papaverin ile Karşılaştırılması.
}

Orhan ALTINKURT * Yusuf ÖZTÜRK * *

\section{SUMMARY}

The experiments were performed by using isolated rat duodenum. Rutin, a natural flavonoid compound, caused relaxations of the rat duodenum dose-dependently. The relaxant effect of rutin on the rat duodenum was examined in comparison with that of adrenaline, isoprenaline and papaverine. In addition, propranolol, a beta-adrenergic blocking agent, phentolamine, an alpha-adrenergic blockingagent and nicotinic acid, an adenyl cyclase inhibitor were used as tools to investigate mechanism of the relaxant effect of rutin on the rat duodenum in vitro.

\section{ÖZET}

Deneyler izole sıçan duodenumu kullanılarak sürdürüldü. Doğal bir flavonoid bileşiği olan rutin doza bağımlı biçimde sıçan duodenumunu gevşetti. Rutin'in sıçan duodenumundaki gevşetici etkisi adrenalin, izoprenalin ve papaverin ile karşılaştırmalı olarak incelendi. Ayrıca, rutin'in sıçan duodenumundaki gevşetici etkisinin mekanizmasını araştırmak için beta-adrenerjik bloker olan propranolol, alfaadrenerjik bloker olan fentolamin ve bir adenil siklaz inhibitörü olan nikotinik asid de kullanıldı.

Key words: Rutin, Adrenaline, Isoprenaline, Papaverine, Phentolamine, Propranolol, Nicotinic acid, Smooth muscle.

Rutin is found in many plants, particularly extracts from Fagopyrum esculentum, Fagopyrum cymosum, Fagopyrum tataricum

Redaksiyona verildiği tarih: 19.2.1987

* Dept. Pharmacol., Fac. Pharm., Univ. Ankara.

** Dept. Pharmacol., Fac. Pharm., Univ. Anatolia. 
(Polygonaceae), Ruta chalepensis, Ruta graveolens (Rutaceae) and Viola tricolor, Viola lutea splendens (Violaceae). Chemically, it is a flavon glycoside with a structure of 3,3', 4', 5,7-pentahydroxyflavone3 -rutinoside. It is known that the flavonoid compounds, such as rutin, possess vitamin $\mathrm{P}$ activity and exert their pharmacological effects by a direct vasoconstriction on the capillary bed. Subsequently, these compounds decrease the permeability and the fragility of the vessels (1). Beside the well-known effects on the vessels, rutin is a non-competitive inhibitor of angiotensin II and prostaglandin $E_{2}$ on the guineapig ileum (2) Apiin and hesperidin which are also known as flavone glycosides exert similar effects on the isolated guinea-pig ileum. The studies on the guinea-pig ileum showed that hesperidin is a non-competitive inhibitor of angiotensin II and bradykinin. Furthermore, apiin is capable to antagonize bradykinin in a non-competitive manner (3). The aim of this study is to confirm the relaxant action of rutin and to approach to its mechanism of action on smooth muscle.

\section{EXPERIMENTAL}

\section{Materials}

Adrenaline (Epinephrine bitartarate, Sigma), Atropine sulphate (Sigma), Isoprenaline sulphate (Ilsan), Nicotinic acid (J.T. Baker), Papaverine hydrochloride (Sigma), Phentolamine methansulphonate (Ciba), Propranolol hydrochloride (Doğu), Rutin (Dilmen). All dilutions, except of papaverine, were prepared with fresh Krebs' solution. Papaverine was dissolved in saline.

\section{Methods}

\section{Isolated rat duodenum}

The isolated rat duodenum was prepared according to the method described by HORTON (4) with minor modifications. The proximal $2 \mathrm{~cm}$ of duodenum from rats weighing 150-200 g was removed after killing and kept in atropinized $(0.143 \mathrm{mM})$ Krebs' solution at $6{ }^{\circ} \mathrm{C}$ for two hours. In this way spontaneous movements were diminished. Then, the duodenum was suspended in a $10-\mathrm{ml}$ organ bath filled with atropinized Krebs' solution and aerated with a mixture of 95 per cent $\mathrm{O}_{2}$ and 5 per cent $\mathrm{CO}_{2}$.

The relaxations of rat duodenum were recorded with an isotonic transducer (Ugo Basile, No. 7006) connected to a recording micro- 
dynamometer (Ugo Basile, No. 7050). The load on the tissue was 1.00 g. The relaxations were magnified 8 -folds.

The suspended duodenum was allowed to equilibrate for $60 \mathrm{~min}$. During this period duodenum was washed out every $15 \mathrm{~min}$. After this initial incubation, dose-response relationships were obtained for an agonist using two non-cumulative dose-response procedure in all experiments. The agonists were adrenaline, isoprenaline and papaverine. Rutin was also used as agonist in this preparation. In each experiment, only one concentration of an antagonist was tested. The drugs used as antagonists were propranolol, phentolamine and nicotinic acid. The isolated rat duodenum was incubated with these drugs for $5 \mathrm{~min}$ and then same dose-response procedure were repeated in the presence of these drugs.

\section{Analysis of data and statistics}

In order to evaluate the actions of agonist and antagonists on the rat duodenum, $\mathrm{pD}_{2}, \mathrm{pD}_{2}^{\prime}$ and $\mathrm{pA}_{2}$ values were calculated in a manner consistent with the method described by ARIENS and VAN ROSSUM (5).

All values reported represent the results of individual experiments. The dose-response curves obtained in the absence and in the presence of antagonists were analysed by means of linear regression procedure (6).

\section{RESULTS AND DISCUSSION}

The main purpose of this study was to approach to the mechanism of inhibitory effect of rutin on smooth muscle in vitro. The previous results obtained on the guinea-pig ileum showed that rutin exerts non-specific interactions angiotensin II and prostaglandin $\mathrm{E}_{2}$ through a common mechanism (2). According to the current concepts (8), if a drug exerts non-competitive and non-specific interactions with some agonists through a common mechanism on an isolated organ, it should possibly act on same receptor-coupled effector system. Therefore, rutin may asct on such an effector system in regard to smooth muscle relaxant action. At this point, it should be thought what the effector system is.

Catecholamines may cause relaxations of some smooth muscles (8-14), some vascular smooth muscles (8, 15-17), uterus (8, 18-23). The action of catecholamines son these muscles is mainly due to beta- 


\section{Orhan ALTINKURT, Yusuf ÖZTÜRK}

adrenoceptor activation and able to be blocked by beta-adrenergic blocking agents (12-14, 17, 19). Cyclic adenosine-3', 5'-monosphosphate (cyclic AMP) is believed to be the intracellular mediator of the effect of beta-adrenoceptor activation in the smooth muscles mentioned above (12-23). On the other hand, alpha-adrenoceptor activation may also cause relaxation of intestinal smooth muscle (9, 12-14). This relaxation is most probably resulting from calcium efflux.

In our experiments, rutin (in a concentration range of $5 \% \mathrm{~g} / \mathrm{ml}$ to $160 \mathrm{ug} / \mathrm{ml}$ ) caused relaxations of rat duodenum dose-dependently. The $\mathrm{pD}_{2}$ value which is direct measure for the affinity of the drugs to site of action was calculated for the relaxant actions of adrenaline, isoprenaline, papaverine and rutin on the rat duodenum by means of ARIENS and VAN ROSSUM's procedure (5). The relaxant effect of rutin on the rat duodenum was examined by comparison of these p D 2 values (Table I).

Table I. Affinity constants $\left(\mathrm{pD}_{2}\right)$ and slopes of dose-response curves $(\mathrm{m})$ of adrenaline, isoprenaline, papaverine and rutin on the isolated rat duodenum.

\begin{tabular}{|l|cc|c|c|}
\hline Relaxant Agent & $\mathrm{pD}_{2} \pm \mathrm{SEM}$ & $\mathrm{m} \pm \mathrm{SEM}$ \\
\hline Adrenaline & $6.873 \pm 0.008$ & $70.904 \pm 0.288$ \\
Isoprenaline & 8.242 & \pm 0.004 & $71.418 \pm 0.360$ \\
Papaverine & 7.498 & \pm 0.001 & $72.879 \pm 0.282$ \\
Rutin & $4.671 \pm 0.001$ & $35.207 \pm 0.052$ \\
\hline
\end{tabular}

SEM: Standard error of mean ( $n=12$ for each relaxant agent)

Phentolamine, alpha-adrenergic blocking agent, inhibited the relaxations elicited by all agonists, non-competitively. It is likely that these inhibitions are not due to alpha -adrenergic blockade, because the concentration of phentolamine which was tested in this study is higher than the concentration required for alpha-adrenergic blockade. Confirmatively, it is well-known that papaverine does not possess any adrenergic activity and its effect on smooth muscle is also not due to catecholamine release. However, the relaxation of rat duodenum elicited by papaverine were inhibited by phentolamine. According to our unpublished results, phentolamine causes an inhibition of calciuminduced contraction of $\mathrm{K}+$-depolarized rat duodenum (24). Therefore it likely that the inhibitory effect of phentolamine on the rat duodenum against adrenaline, isoprenaline, papaverine and rutin accurs as a consequence of this calcium antagonistic action. 
Propranolol, beta-adrenergic blocking agent inhibited the relaxations elicited by adrenaline and isoprenaline, non-competitively, but did not inhibit rutin and papaverine relaxations. This finding confirms the results obtained by ANTONIO (11). Seeing that rutin -induced rat duodenum relaxations were not inhibited by propranolol, it might be thought that the relaxant effect of rutin on smooth muscle does not occur as a result of catecholamine relaease or catecholamme-like action.

Another intersting point was that, nicotinic acid is able to inhibit adrenaline- and isoprenaline-induced relaxations of rat duodenum. These inhibitions are competitive in nature. It is known that nicotinic acid is an inhibitor of adenyl cyclase (25). Therefore, these competitive inhibitions should not be a surprise, since beta-adrenoceptors are coupled by adenyl cyclase. In fact, it has been suggested that betaadrenoceptors are identical with adenyl cyclase (26). However, under the light of recent studies, it seems likely that the suggestion is out of fashion (27). On the other hand, nicotinic acid did not affect the relaxant effect of rutin on the rat duodenum as well as papaverine. This finding strongly suggests that the inhibitory effect of rutin on smooth muscle is not owing to adenyl cyclase activation. Table II shows the $\mathrm{pD}_{2}^{\prime}$ and $\mathrm{pA}_{2}$ values representing the interactions of adrenaline, isoprenaline, papaverine and rutin with phentolamine, pranolol and nicotinic acid on the rat duodenum.

Confirmatively, it has been observed that the flavonoid compounds inhibit phosphodiesterase (PDE) which is known as cyclic AMPdegrading enzyme (28). Similarly, papaverine which is well-known PDE inhibitor causes smooth muscle relaxation (29). Therefore, it might be proposed that rutin-induced relaxation is related with PDE inhibition. However, the slope of rutin calculated from its dose-response curves is much less then those of adrenaline, isoprenaline and papaverine (Table I) suggesting the difference in the mechanism of action of rutin. Therefore, it would be of interest to investigate possible interference of calcium ions and calmodulin which are important factors in the smooth muscle regulation. 
Table.II. Effects of propranolol, phcntolamine and nicotinic acid on adrenaline-, isoprenaline-, papaverine- and rutin-induced relaxations of the isolated rat duodenum in vitro.

\begin{tabular}{|l|c|c|c|}
\hline \multirow{2}{*}{ Relaxant Agent } & \multicolumn{2}{|c|}{ Phentolamine } & \multicolumn{2}{c|}{ Propranolol } & \multicolumn{2}{c|}{ Nie. Acid. } \\
& $\mathrm{pD}^{\prime}{ }_{2} \pm \mathrm{SEM}$ & $\mathrm{pD}^{\prime}{ }_{2} \pm \mathrm{SEM}$ & $\mathrm{pA} \pm$ SEM \\
\hline Adrenaline & $4.025 \pm 0.064$ & $5.141 \pm 0.013$ & $3.852 \pm 0.089$ \\
Isoprenaline & $4.031 \pm 0.042$ & $4.915 \pm 0.058$ & $3.857 \pm 0.121$ \\
Papaverine & $4.069 \pm 0.103$ & 2.650 & 0.848 \\
Rutin & $3.902 \pm 0.043$ & 2.776 & 0.867 \\
\hline
\end{tabular}

$\mathrm{pD}^{\prime}{ }_{2} \quad$ : Non-competitive antagonist affinity constant

$\mathrm{pA}_{2}{ }_{2} \quad$ : Competitive antagonist affinity constant

SEM : Standard error of mean ( $n=5$ for each set of experiment)

\section{I T E R A T U R}

1- Lanan, H., Purucker, H., Bioflavonoide,"Vitamin P"., Amon, R., Dirscherl, W. (Ed,s) (Eds), Fermente, Hormone, Vitamine und die Beziehungen dieser Wirkstoffe zueinander, Bd. 3 (1), Georg Thieme Verlag, Stuttgart (1974).

2- Altınkurt, O., Abacoglu, N., Non-competitive inhibition of angiotensin II and PGE2 on guinea-pig ileum with streptomycin, vitamin K3 and rutin., Arzneim. Forsch. 30, 610-5613 (1980).

3- Leme, J.G., Walaszek, E.J., Antagonists of pharmacologically active peptides: Effects on quinea-pig ileum and inflammation, Pharmacologist 7, 242 (1967).

4- Horton, E., Human urinary kinin excretion, Br. J. Pharmacol., 14, 125-132 (1959).

5- Ariens, E.J., Van Rossum, J.M., pDx, pAx and pD; values in analysis of pharmacodynamics, Arch. Int. Pharmacodyn. Ther., 110, 275-299 (1957).

6- Goldstein, A., (Ed.), Bioslatistics. An introductory text, Mac Millan, New York (1964).

7- Crossland, J., (Ed.), Receptors, Lewis's Pharmacology, Churchill Livingstone, London (1980),

8- Vogin, E.E., Baker, W.W., Dichloroisoproterenol and the beta-adrenergic receptor, Am. J. Pharm., 133, 314-326 R(1961).

9- Harry, J., The site of action of sympathomimetic amines on the circular muscle strip from the guinea-pig isolated ileum, J. Pharm. Pharmacol., 16, 332-336 (1964).

10 - Wilson, A.B., Beta sympathetic inhibitory receptors in the small intestine of the guineapig, J. Pharm. Pharmacol, 16, 834-835 (1964).

11 - Antonio, A., The relaxing effect of bradykinin on intestinal smooth muscle, Br. J. Phararmacol., 32, 78-86 (1968).

12. Andersson, R., Lundholm, E.M., Studies on the relaxing actions mediated by stimulation of adrenergic alpha-and beta-receptors in taenia-coli of the rabbit and guinea-pig. Acta Physiol. Scand., 77, 372-384 (1969).

13- Andersson, R., Lundholm, E.M., Metabolic actions in intestinal smooth muscle associated with relaxation mediated by adrenergic alpha- and beta- receptors, Acta Physiol. Scand. 79, 244-261 (1970). 
14- Andersson.R., Role of the cyclic AMP and Ca2+ in the metabolic and relaxing effects of catecholamines in intestinal smooth muscle, Acta Physiol. Scand., 85, 312-322 1972).

15- Somlyo, A.P., Somlyo, A.V., Vascular smooth muscle. II. Pharmacology of normal and hypertensive vessels, Pharmacol. Rev., 22, 249-353 (1970).

16- Guimares, S., The slopes of cumulative and non-cumulative dose-response curves for noradrenaline and isoprenaline, Europ. J. Pharmacol., 17, 44-49 (1972).

17- Al-Jeboory, A., Marshall, R.J., Relaxant effects of dopamine and isoprenaline on canine isolated arteries-relationship to cyclic AMP, Br. J. Pharmacol., 62, 373P-374P (1978).

18- Dobbs, J.W., Robinson, G.A. Functional biochemistry of beta-adrenoceptors in rat uterus, Fed. Proc, 27, 2352 (1968).

19- Polacek, I., Daniel, E.E., Effect of alpha- and beta-adrenergic stimulation on the uterine motility and adenosine 3', 5'-monophosphate level, Canad. J. Physiol. Pharmacol., 49, 988-998 (1971).

20. Kroeger, E.A., Marshall, J.M., Beta-adrenergic effects on rat myometrium: Role of cyclic AMP, Am. J. Physiol., 226; $1298-1303$ (1974).

21 - Owerweg, N.I.A., Schiff, J.D., Two mechanism of isoproterenol inhibition of smooth muscle, Europ. J. Pharmacol., 47, 231-233 (1978).

22. Johansson, S.R.M., Andersson, R.G.G., Effects of isoprenaline on the time course of cyclic A M P level in rat uterus, Acta Pharmacol. Toxicol, 42, 347-353 (1978).

23 - Meisheri, K.D., McNeill, J.H., Role of Ca2(+) in isoprenalinc-induccd increases in cyclic AMP in rat uterus, Am. J. Physiol., 237, C257-263 (1979).

24 - Altınkurt, O., Öztürk, Y., Unpublished observations (1984).

25 - Grodsky, G.M., General characteristics of hormones, Harpers, H.A., Rodvwell, V.W., Mayes, P.A. (Eds), Review of Physiological Chemistry, Lange, Los Altos (1979).

26 - Robison, G.A., Butcher, R..W., Sutherland, E.W., Adenyl cyclase as an adrenergic receptor, Ann. N.T. Acad. Set., 139, 703-723 (1967).

27 - Minocherhomjee, A.M., Roufogalis, B.D., Mechanisms of coupling of the betaadrenergic receptor to adenylate cyclase-an overview, Gen. Pharmacol., 13, 87-93 (1982).

28 - Beretz, A., Anton, R., Stoclet, J.C., Flavonoid compounds are potent inhibitors of cyclic AMP-phosphodicsterase, Experientia 34, 1054-1055 (1978).

29- Kukovetz, W.R., Juan, H., Pöch, G., Zum mechanismus der Papaverinewirkung au der isolierte Coronarge asse, N.-S. Arch. Pharmak. exp. Path., 264 262-263 ¿(1969). 


\section{YAYIM KOŞULLARI}

1- Bu dergide aşağıda belirtilen koşullara uyan ve bilimsel danışmanların yayımlanabilir nitelikte bulduğu, daha önce hiçbir yerde yayımlanmamış olan orijinal makaleler yayımlanır.

2- Metinler, şekiller hariç 10 daktilo sayfasını geçmemelidir. Yazıların dil kurallarına uygunluğundan yazarlar sorumludur.

3 - Metinler 3 nüsha olarak A-4 formatta $(21.0$ x $29.7 \mathrm{~cm})$ kağıdın bir yüzüne normal puntolu daktilo ile 2 aralıklı olarak yazılmalı, kağıdın alt ve üst kenarından $2 \mathrm{~cm}$, sol kenarından $3 \mathrm{~cm}$ ve sağ kenarından $1.5 \mathrm{~cm}$ boşluk bırakılmalıdır. Klişesi yapılacak grafik, şema, formül gibi şekiller aydınger kağıdına çini mürekkebi ile çizilmeli; fotoğraflar parlak kağıda kontraslı olarak basılmalıdır. Her şeklin arkasına yazar adı, şekil no. su ve küçültme oranı yazılmalı ve 2., 3. nüshalar için şekillerin fotokopisi eklenmelidir.

4- Yazı plânı aşağıdaki şekilde olmalıdır:

Makale başlı̆̆ı, makalenin yabancı dilde başlı̆̆ı, yazar adı (yazar adları), Türkçe özet yabancı dilde özet, anahtar kelimeler, giriş, denel kısım, sonuç ve tartışma, teşekkür, literatür.

Özetler türkçe ve yabancı dilde en çok 100'er kelimeden oluşmalıdır.

Giriş bölümü en çok 2 sayfa ve başlıksız olarak yazılmalıdır. Materyal ve Metod alt başlıklar halinde, Denel kısımda bulunmalidir.

Sonuç ve Tartışma kısmı bulguları da içermelidir.

Literatürler, makalede parantez içindeki numaralarla belirtilmeli ve makale sonunda bu numaralara göre sıralanmalıdır.

Literatürler: Yazarın Soyadı (siyah), adının ilk harfi (siyah), makale adı, derginin adı (italik) veya kitabın adı, cilt no (siyah) sayı (parantez içinde), sayfa numarası ve yıl (parantez içinde) olarak yazılmalıdır.

5- Tashihler yazar tarafindan yapılacaktır.

6- Yazara 20 ayr1 bask1 verilir. 